【論文】

\title{
高圧水素用バーネット式 PVT 性質測定装置の開発 Development of a PVT Property Measurement Apparatus by the Burnett Method for High Pressure Hydrogen
}

\author{
迫田直也*，進藤健太**，新里寛英***，河野正道**， \\ 高田保之**, 藤井丕夫*** \\ Naoya SAKODA, Kenta SHINDO, Kan'ei SHINZATO, Masamichi KOHNO, \\ Yasuyuki TAKATA, Motoo FUJII
}

\begin{abstract}
高圧水素の PVT 性質測定を目的として, 常温から $523 \mathrm{~K}, 100 \mathrm{MPa}$ までの温度，圧力領域で測定可 能なバーネット式PVT 性質測定装置を開発した . 本測定装置は安全かつ効率的に実験を行うため, 試 料の昇圧から測定まで, 全て遠隔で操作できるように設計されている.室素の PVT 性質を $353 \mathrm{~K}$ にお いて $100 \mathrm{MPa}$ まで測定し, 既存の状態方程式と比較した結果, $0.22 \%$ 以内で良好に一致した .乥して， 同樣に $353 \mathrm{~K}$ において水素の PVT 性質を $100 \mathrm{MPa}$ まで測定することができ，既存の水素の状態方程 式は本実測值と $0.22 \%$ 以内で一致した .
\end{abstract}

A PVT property measurement apparatus based on the Burnett method has been developed for high pressure hydrogen up to $100 \mathrm{MPa}$ in the range from room temperature to $523 \mathrm{~K}$ with safety and efficiency in mind, the apparatus was designed for remote operation and computerized data acquisition. PVT property measurements for nitrogen have been performed up to $100 \mathrm{MPa}$ at $353 \mathrm{~K}$ and they were in good agreement with an existing equation of state (EOS) within $\pm 0.22 \%$. We have finally succeeded in measuring the PVT property of hydrogen up to $100 \mathrm{MPa}$ at $353 \mathrm{~K}$. For these pressure and temperature ranges, the existing EOS for hydrogen is applicable with reasonable accuracy.

[Keywords: Burnett method, high pressure, hydrogen, PVT property]

\section{I．緒言}

水素利用社会の実現に向け，水素物性へのニーズが非 常に高まっている . 中でも PVT 性質は最も基本的な物性 であり，状態方程式作成の基盤情報となるため精度の良 い測定データが必要とされている . 水素のPVT 性質は, 1960 年代から 1970 年代にかけて米国 NIST(旧 NBS)と NASA によって，主にスペースシャトル開発用に液体水

* 九州大学水素エネルギー国際研究センター, , 819-0395 福岡 市西区元岡 744.

International Research Center for Hydrogen Energy, Kyushu University, 744 Motooka, Nishi-ku, Fukuoka 819-0395.

FAX: 092-802-3263 E-mail: sakoda@mech.kyushu-u.ac.jp

** 九州大学機械工学部門, = 819-0395 福岡市西区元岡 744.

Department of Mechanical Engineering, Kyushu University, 744 Motooka, Nishi-ku, Fukuoka 819-0395.

***産業技術総合研究所水素材料先端科学研究センター,

于 819-0395 福岡市西区元岡 744.

Research Center for Hydrogen Industrial Use and Storage, National Institute of Advanced Industrial Science and Technology (AIST), 744 Motooka, Nishi-ku, Fukuoka 819-0395.
素を中心として , 三重点温度である $14 \mathrm{~K}$ から $300 \mathrm{~K}, 100$ MPa までの領域で体系的に測定されている[1,2] .しかし， 将来の水素社会で必要とされる高温, 高圧域における実 測值は十分とは言えないのか現状である．Table 1 に最大 圧 $50 \mathrm{MPa}$ 以上の高圧 , あるいは最高温度 $473 \mathrm{~K}$ 以上の高 温におけるバーネット法[3]を用いた測定例を示す . 1975 年以前の測定についてはLe Neindre and Vodar [4]によるレ ヴューがある . Cramer [5]はへリウムと窒素の混合物およ びヘリウムと重水素の混合物を $140 \mathrm{MPa}$ の高圧域まで測 定しているが, 兴の温度は $298 \mathrm{~K}$ に限られる.また， Canfield et al.[6-9] (83 K〜323 K ,71 MPa まで)や Briggs et al. [10-11] (123 K〜323 K , $100 \mathrm{MPa}$ まで) は低温, 高圧 域においてへリウム, 窒素, アルゴンといった不活性ガ スを対象として , Patek et al. [12]は $423 \mathrm{~K}$ という比較的高 い温度において50 MPa までの領域でHFC-227eaの測定を 行っている .一方 , 高温の測定では, Wintonsky and Miller [17]が748 Kという非常に高い温度領域まで測定している が , 総じて $473 \mathrm{~K}$ 以上の温度領域では $25 \mathrm{MPa}$ 以下の圧力 
となっている．

Table 1 Previous high pressure or high temperature measurements by the Burnett method.

\begin{tabular}{|c|c|c|c|}
\hline First Author & Substances & $\begin{array}{c}\text { Temp. range } \\
\text { / K }\end{array}$ & $\begin{array}{c}\text { Max. } \\
\text { Pressure } \\
/ \mathrm{MPa}\end{array}$ \\
\hline \multicolumn{4}{|c|}{ High pressure measurements (Max. $P \geq 50 \mathrm{MPa}$ ) } \\
\hline Cramer [5] & $\begin{array}{c}\mathrm{He}, \mathrm{He}-\mathrm{N}_{2}, \\
\mathrm{He}-\mathrm{D}_{2}\end{array}$ & 298 & 140 \\
\hline Canfield [6] & $\mathrm{He}, \mathrm{N}_{2}, \mathrm{He}-\mathrm{N}_{2}$ & $133 \sim 273$ & 54 \\
\hline Blancett [7] & $\mathrm{He}-\mathrm{Ar}$ & $223 \sim 323$ & 70 \\
\hline Provine [8] & $\mathrm{He}-\mathrm{Ar}$ & $143 \sim 183$ & 71 \\
\hline Hall [9] & $\mathrm{He}-\mathrm{N}_{2}$ & $83 \sim 113$ & 70 \\
\hline Briggs [10] & $\mathrm{He}$ & $123 \sim 273$ & 80 \\
\hline Briggs [11] & $\mathrm{He}, \mathrm{N}_{2}, \mathrm{He}-\mathrm{N}_{2}$ & $273 \sim 323$ & 100 \\
\hline Patek [12] & HFC-227ea & $393 \sim 423$ & 50 \\
\hline
\end{tabular}

High temperature measurements (Max. $T \geq 473 \mathrm{~K}$ )

\begin{tabular}{lccc}
\hline Waxman [13] & $\mathrm{Ar}, \mathrm{CO}_{2}$ & $273 \sim 498$ & 25 \\
Silberberg [14] & $i-\mathrm{C}_{5} \mathrm{H}_{12}$ & $323 \sim 473$ & 5 \\
Vohra [15] & $i-\mathrm{C}_{5} \mathrm{H}_{12}$ & $448 \sim 473$ & 18 \\
Belzile [16] & $\mathrm{CHF}_{3}$ & $273 \sim 473$ & 17 \\
Witonsky [17] & ${\mathrm{He}-\mathrm{N}_{2}}$ & $448 \sim 748$ & 10 \\
\hline
\end{tabular}

このような現状にあって，本研究では $100 \mathrm{MPa}$ までの 高圧域，しかも $523 \mathrm{~K}$ の高温領域においても適用可能な 水素の PVT 性質測定装置を開発し，窒素 ,ヘリウムおよ び水素の PVT 性質の測定を試みる . 測定装置は試料の質 量測定を必要としないバーネット法を適用したもので， 低密度域での測定に非常に有効とされている. 本研究で 測定対象としている温度, 圧力領域では, 水素は超臨界 状態となるが ,乥の密度は $100 \mathrm{MPa}$ の高圧であっても 298 $\mathrm{K}$ で $24.5 \mathrm{~mol} \mathrm{dm}^{-3}\left(=49.4 \mathrm{~kg} \mathrm{~m}^{-3}\right)$ 程度とかなり小さく , バ 一ネット法が適用できる．なお，高圧水素に関する実験 は取り扱いに注意を要するため, 安全かつ効率的に実験 が行えるように, 本測定装置は遠隔操作が可能な仕樣と なっている .

\section{2 . 測定原理}

\section{1 測定手順}

バーネット法による測定装置は Fig. 1 に示すように， 大小 2 つの容器から成る . バーネット法は大きな試料 容器(A)から小さな膨張容器(B)へ気体を等温膨張させ , 膨張前後の圧力を測定することで, 各膨張時における 圧縮係数 $Z$ ならびに密度 $\rho$ を求める方法である . 温度
1. Insert the sample into

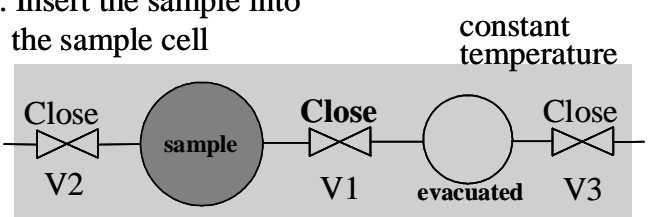

(A) sample cell

(B) expansion cell

$\left.\begin{array}{l}\text { 2. Open the V1 and } \\ \text { expand the sample }\end{array}\right\} \begin{array}{r}3 . \text { Evacuate the sample } \\ \text { in the expansion cell }\end{array}$

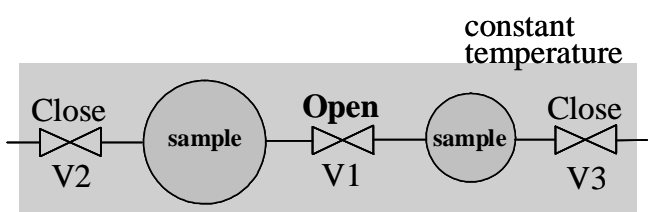

$\begin{array}{ll}\text { (A) sample cell } & \text { (B) expansion cell }\end{array}$

Fig. 1 Procedures of the Burnett method.

制御や圧力測定に高い精度が要求されるが, 充填質量や 圧力容器の内容積を直接測定する必要がない利点を有し ている。

\section{2 密度の算出手順}

各膨張時における圧力測定から密度を算出する手順を 以下に示す 容積 $V_{\mathrm{A}}$ の試料容器に質量 $m$ の試料が温度 $T$, 圧力 $P_{i-1}$ で充填されている場合，実在流体は圧縮係数 $Z_{i-1}$ を用いて，式(1)のように表される .

$$
P_{i-1} V_{\mathrm{A}}=Z_{i-1} m R T
$$

ここでRはガス定数であり，下付きの添字 $i$ は膨張回数を 表す この試料を容積 $V_{\mathrm{B}}$ の膨張容器に等温膨張したとき， 体積か変化するため, 式(2)のように記述できる .

$$
P_{i}\left(V_{\mathrm{A}}+V_{\mathrm{B}}\right)=Z_{i} m R T
$$

式(2)を式(1)で割ると式(3)になる

$$
\frac{P_{i}\left(V_{\mathrm{A}}+V_{\mathrm{B}}\right)}{P_{i-1} V_{\mathrm{A}}}=\frac{Z_{i}}{Z_{i-1}}
$$

ここで, $\left(V_{\mathrm{A}}+V_{\mathrm{B}}\right) / V_{\mathrm{A}}=N$ とすると, 式(3)は,

$$
\frac{P_{i}}{P_{i-1}} N=\frac{Z_{i}}{Z_{i-1}}
$$

となる.この $N$ は通常，装置定数と呼ばれ，膨張比を意 味する. 試料容器から膨張容器への等温膨張を無限回行 ったとすると，流体は理想気体状態となり， $Z=1$ とみな すことできるため，式(5)で表されるように膨張前後の圧 力比から $N$ が決定できる . 


$$
N=\lim _{i \rightarrow \infty} \frac{Z_{i}}{Z_{i-1}} \frac{P_{i-1}}{P_{i}}=\lim _{i \rightarrow \infty} \frac{P_{i-1}}{P_{i}}
$$

また ,式(4)において,$i=1 \sim n$ まで辺々を掛け合わせると，

$$
\frac{P_{n}}{P_{0}} N^{n}=\frac{Z_{n}}{Z_{0}}
$$

となる . 無限回等温膨張を行ったとすると,$Z_{n}=1$ とみな せるので, 式(7)より初期圧縮係数 Z $Z_{0}$ か浗まる .

$$
\lim _{n \rightarrow \infty}\left(\frac{P_{n}}{P_{0}} N^{n}\right)=\frac{1}{Z_{0}}
$$

$Z_{0}$ が求まると， $Z_{n}$ は式(6)より

$$
Z_{n}=Z_{0}\left(\frac{P_{n}}{P_{0}} N^{n}\right)
$$

として, 全ての膨張過程の各圧力における圧縮係数が求 まる. 圧縮係数 $Z$ は式(1)で定義されているので, 密度 $\rho$ は , 次式(9)から算出される .

$$
\rho=\frac{m}{V}=\frac{P}{Z R T}
$$

\section{3 . 測定装置}

\section{1 圧力容器の構造}

$523 \mathrm{~K}, 100 \mathrm{MPa}$ の耐熱, 耐圧性を有する試料容器と膨

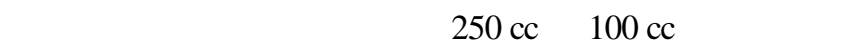
である.これらの容器のシール構造や肉厚はいずれも等 しく, 円筒形部分の内径 $35 \mathrm{~mm}$, 外径 $85 \mathrm{~mm}$ であり，内 筒の容積のみ異なっている.Fig. 2 に試料容器の構造を示 す 容器の肉厚は国内法規に則り安全率を 4 としており， 外形を可能な限り小さくするため, 容器及び恒温槽内の 配管には, 引っ張り強度力強く高温でも劣化しないイン コネル 625 を用いている . 図に示すように , 圧力容器の シール部分は, ガスケットと部品 B の接触角度が 55 度と 60 度の 5 度の差がくように設計され, 内圧がかかと ガスケットか部品 B に押しつぶさされて，より強固にシー ルされる構造となっている .

\section{2 装置概要}

本装置全体の概要を Fig. 3 に示す.試料の圧力測定には 高精度な水晶発振式圧力センサ(Paroscientific 社製 420K-101，最大圧カレンジ $138 \mathrm{MPa}$ )を用いており，少の

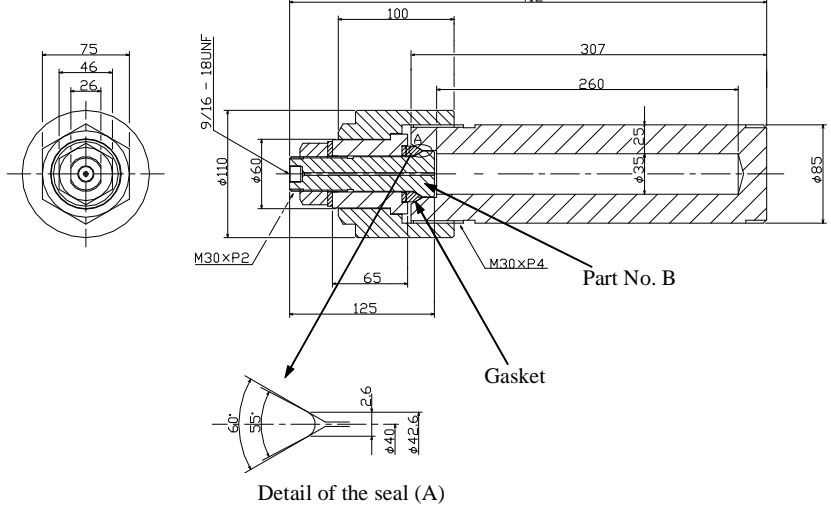

Fig. 2 Structure of the sample cell $(250 \mathrm{cc})$.

不確かさはフルスケールの $0.01 \%$ \%である . シリコーンオ イルを熱媒体とする恒温槽を使用し，温度は標準白金抵 抗測温体(NETSUSHIN 社製 NSR-660)と精密級交流ブリ ッジ(A $\Lambda$ 社製 F700B)を用いて ITS-90 国際温度目盛に準 拠した測定を行っている.試料は純度 $99.999 \%$ の水素， 室素およびへリウムを用いており, $18.72 \mathrm{Nm}^{3} \mathrm{day}^{-1}$ の処理 能力を有する二段式圧縮の圧縮機を用いて $100 \mathrm{MPa}$ まで 昇圧される .

試料容器, 膨張容器とこれらを接続する 3 個のバルブ て構成される本装置中心部分の立体図を Fig. 4 に示す.配 管は，減肉の恐れのある溶接や曲げを行わず，全て継手 によって接続している.試料容器と膨張容器の間には, MV1 で示した高圧仕樣のメータリングバルブを挿入して おり，膨張時の圧力の急激な变化を抑える役割を担って いる.MV1 を除くV1〜V3 のバルブは, 遠隔操作が可能 なエアーアクチュエータ式のバルブである . 実験室内に は,バルフ駆動用に圧縮空気 $0.6 \mathrm{MPa}$ がガス供給ポートか ら供給されており，防爆仕樣の電磁弁を操作しバルブの 駆動空気を供給あるいは大気開放することにより，エア ーアクチュエータ式のバルブを開閉する仕組になってい る.Fig. 4 に示したV1, V2, V3 の 3 個のバルブは , 等温膨 張という実験条件から，バルブのボディーを恒温槽深く に浸す必要があるため, 通常の市販品よりもステム部分 を長くした仕樣になっている . ステム駆動部分のパッキ ンには高温でも耐えられるグラフォイルを用いている . 駆動部分のパッキンは, 水素が漏れず, かつステムが可 動する程度に適度に強くシールされている必要がある。 バルブにはリーク検知用の検出孔か設けられていて， ス テムからの水素のリークの有無は, $10 \mathrm{ppm}$ という低濃度 を感知できる携帯式の接触燃焼式高感度水素センサを用 いて確かめることができる．V1 バルブは通常のニードル バルブであり，わずかではあるが , バルブの開閉によっ 
て, 試料容器と膨張容器の膨張比か変化することを避け るため, 圧力測定は，常にV1 を閉じた状態で行う．

遠隔操作は主として装置付属の PC によって操作を行 う. 計測ソフトウェア LabVIEW (National Instruments 社 製) を起動し，表示される装置概念図上のスイッチやバ ルブのアイコンを操作することにより，ヒーターや配管 系統に設置されている圧力計, エアーアクチュエータ式 バルブの開閉ができる . また , 圧縮機もタッチパネル付 きの操作盤により遠隔での操作が可能で, 圧縮操作に伴 うバルブの開閉操作は全て自動的に行われる .さらに , 安全のための各種インターロックがプログラムされ, 本 装置の PC と圧縮機の操作盤とは相互通信が行われてい る。

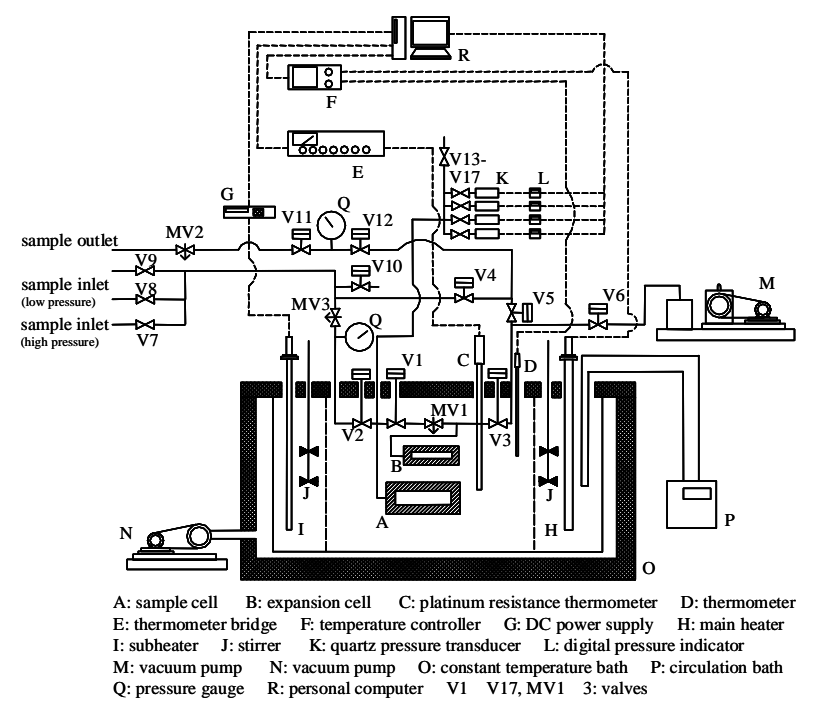

Fig. 3 Schematic diagram of the PVT property measurement apparatus.

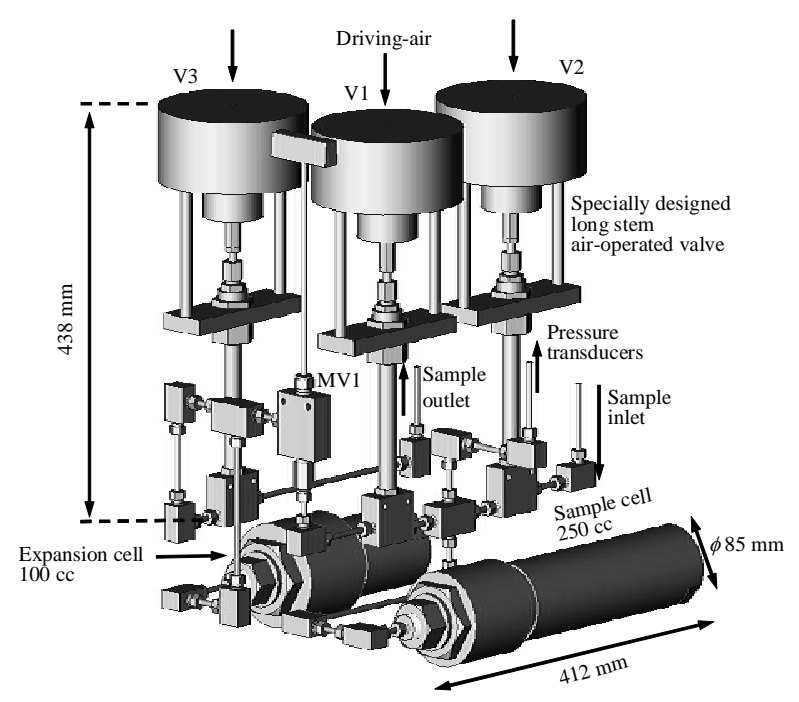

Fig. 4 The sample cell and the expansion cell with three air-operated valves.

\section{3 バルブ制御}

試料容器に充填された $100 \mathrm{MPa}$ の試料を膨張容器に膨 張させると $60 \mathrm{MPa}$ 程度に減圧され, $40 \mathrm{MPa}$ もの圧力変 化が起こる.このような急激な圧力変化は精密圧力セン サにダメージを与える可能性があるだけでなく，配管に 大きな振動や負荷を与え，また断熱圧縮による高温状態 を生じる . 本研究で用いているエアーアクチュエータ式 バルブは, 一部の高額かつ大規模な流量コントロールバ ルブとは異なり，ステムの位置調節を行う機能を有して いない．したがって , バルブの開閉によって瞬間的な圧 力変化が生じる.この急激な圧力変化による危険を避け るため, Fig. 5 に示すように, 防爆仕樣の電磁弁と高圧 バルブの間に低圧仕樣のメータリングバルブとエアーア クチュエータ式バルブを設置し, 高圧仕樣のエアーアク チュエータ式バルブの駆動空気压をコントロールするこ とで, ステムの位置調節が可能な機構を開発した .メー タリングバルブは, 流路を絞って駆動空気圧が緩やかに 変化するようにし, さらに低圧仕樣のエアーアクチュエ 一タ式バルブを閉じることで，任意の駆動空気圧を保持 して，高圧バルブのステムの位置を保持することを可能 にしている．本機構により，段階的に駆動空気を減圧あ るいは加圧していくことで, 高圧バルブを緩やかに開閉 することができる .

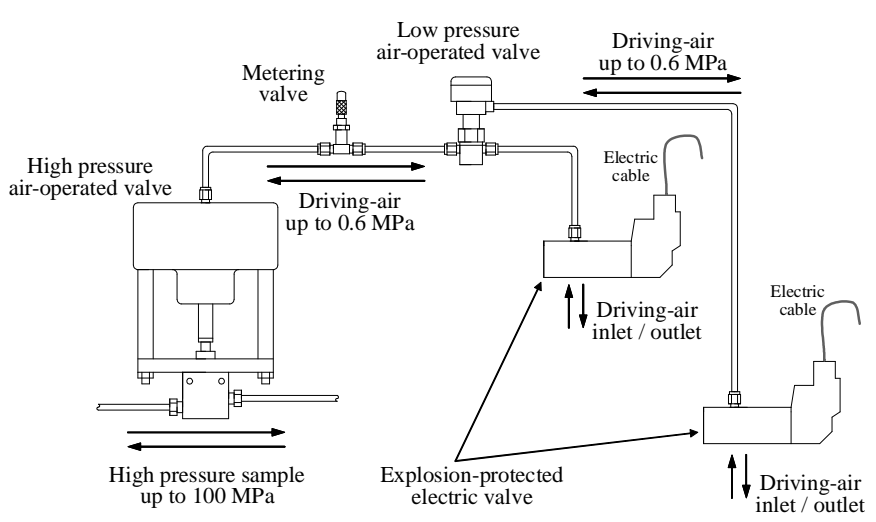

Fig. 5 Air-operated valve control system.

\section{4 . 測定結果}

水素 , 窒素およびへリウムの PVT 性質を $353 \mathrm{~K}$ におい て $100 \mathrm{MPa}$ まで測定した.窒素のPVT 性質は十分に研究 され，精度の良い状態方程式が作成されていることから， 装置の健全性の確認に有効である . 一方でへリウムは， 高温，高圧のデータがほとんど無く，信頼性の高い状態 方程式も作成されていないが, 理想気体に近い挙動は, 装置定数 $N$ の決定に有用である . 水素は再現性の確認の 
ため 2 回の測定を行い，光れ光れ Ser. 1 およびSer. 2 とし た . 恒温槽の温度を $\pm 10 \mathrm{mK}$ 以内で一定に制御し，等温膨 張は初期圧力 $100 \mathrm{MPa}$ の試料容器の圧力が $1 \mathrm{MPa}$ になる まで11〜12 回の膨張を行った . Fig. 6 に水素, 室素およ びヘリウムの各膨張時に測定された圧力を示す . 膨張後 の圧力は各気体の圧縮係数に依存するため, 水素と室素 では第 1 回目の膨張後の圧力が大きく異なるが, 膨張を 繰り返すにつれて, 徐々に理想気体に近づき, 最終的な 圧力変化は気体の種類に依らずほぼ同樣な值となる .

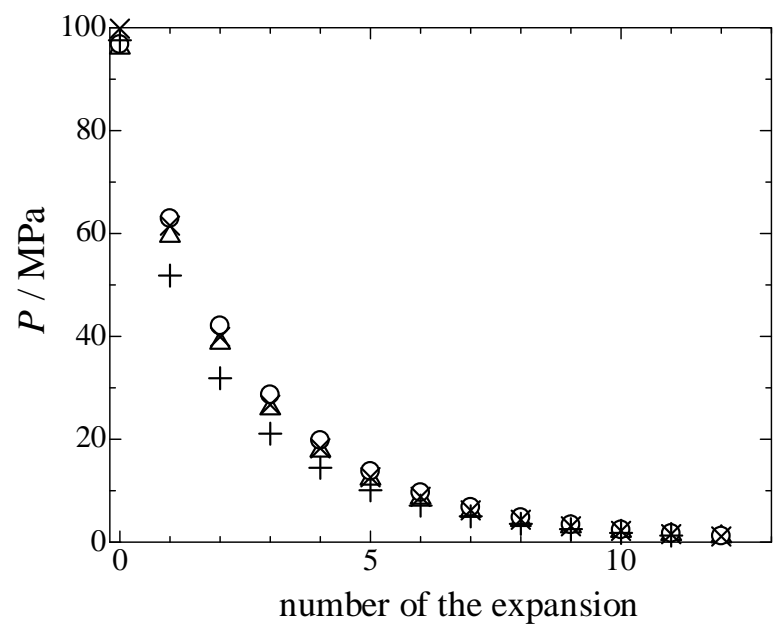

Fig. 6 Pressure measurements of hydrogen, nitrogen, and helium at $353 \mathrm{~K} . \quad(\Delta) \mathrm{H}_{2}($ Ser. $1 ; 353.223 \mathrm{~K}),(X) \mathrm{H}_{2}$ (Ser. 2; $353.249 \mathrm{~K}),(\mathrm{O}) \mathrm{He}(353.225 \mathrm{~K}),(+) \mathrm{N}_{2}$ (353.238 K).

装置定数 $N$ は式(5)で示したように，理論上は膨張を無 限回繰り返すことで求めることができる . しかし, 実際 には無限回繰り返すことは不可能であり，低圧になれば なるほど , 圧力測定の不確かさが相対的に大きくなる . 弚こで Fig.7 に示すように，横軸に圧力，縦軸に圧力比を プロットし,3 次の相関式を用いて切片から装置定数を決 定した .ごく低圧域では, 圧力比は圧力に対して直線と 近似できるが, $100 \mathrm{MPa}$ までの高圧域を相関する場合には 3 次までの次数が必要となる.装置定数の值は物質に依存 しないが，無限回膨張後は理想気体とみなせることを前 提としているため, 理想気体に近い物質で決定すること か望ましい. 水素およびへリウムで装置定数を求めた結 果 , ヘリウムの場合には 1.40516 の值が得られ , 水素の場 合の結果は 2 回ともへリウムの值と $0.01 \%$ 以内で一致し た.結果として, 密度を算出する際の装置定数としては, 最も理想気体に近い挙動を示すへリウムの場合に得られ た值を用いた . 初期充填時の圧縮係数は, 式(7)に示した ように無限回膨張後の值から求めるが, 装置定数の場合
と同樣に無限回の膨張は困難なことから，Fig. 8 に示すよ うに, 水素には 1 次式を, 室素には 3 次式を用いて切片 から初期充填圧縮係数を算出した .

以上より，式(8)および式(9)を用いて室素の密度を算出 し，この結果を Table 2 に示す . また , Span et al. [18]の状 態方程式からの密度偏差を Fig. 9 に示す .この状態方程式 は, $353 \mathrm{~K}, 100 \mathrm{MPa}$ までにおける密度算出の不確かさを 最大で $0.05 \%$ としており，信頼性が非常に高い．本測定 結果はこの状態方程式と $0.22 \%$ 以内で一致している.し たがって, 本測定における密度の不確かさは $0.2 \%$ 程度と 見積もられる.水素に関して ,Fig. 10 に Leachman [19] の ノーマル水素に対する状態方程式との比較を示す． Leachman の状態方程式は 1959 年に測定された Michels et al. [20]の実測值を相関して作成されているが，本測定結果 はこの状態方程式と $0.22 \%$ 以内で一致している.

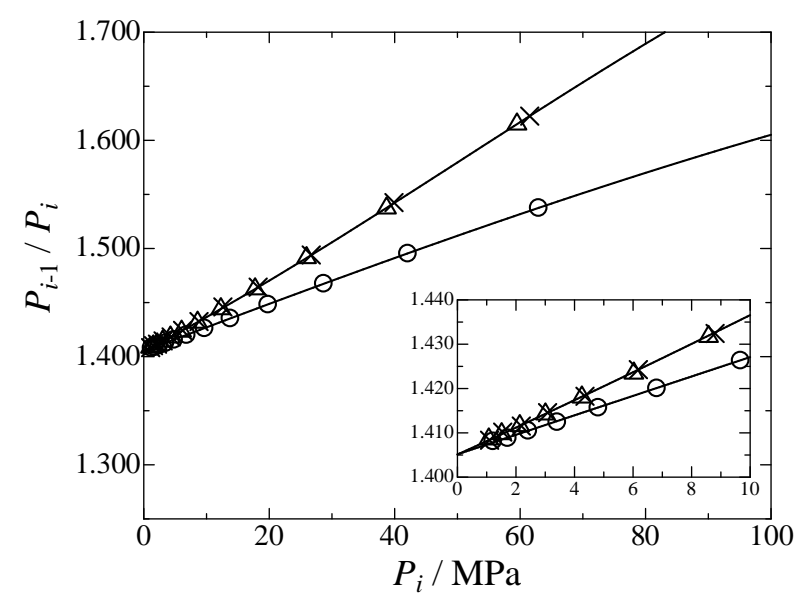

Fig. 7 Determination of the apparatus constant at $353 \mathrm{~K}$. $(\triangle) \mathrm{H}_{2}$ (Ser. 1), ( X) $\mathrm{H}_{2}$ (Ser. 2), ( O ) He.

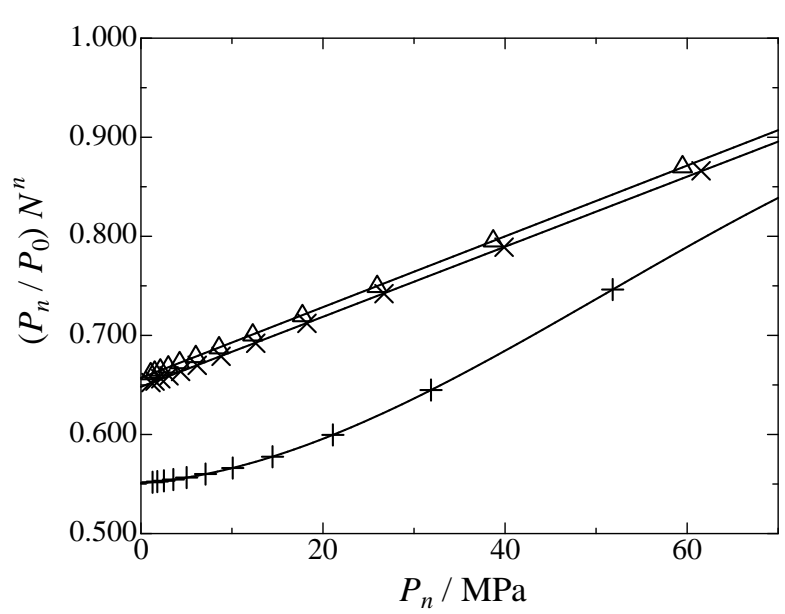

Fig. 8 Determination of the initial compressibility factors of hydrogen and nitrogen. ( $\triangle$ ) $\mathrm{H}_{2}$ (Ser. 1), (X) $\mathrm{H}_{2}$ (Ser. 2), (十) $\mathrm{N}_{2}$. 
Table 2 Experimental results of PVT property for nitrogen at $353.238 \mathrm{~K}$.

\begin{tabular}{cccc}
\hline$P / \mathrm{MPa}$ & $\rho_{\mathrm{exp}} *^{1} / \mathrm{mol} \mathrm{dm}^{-3}$ & $\rho_{\text {cal }} *^{2} / \mathrm{mol} \mathrm{dm}^{-3}$ & $\mathrm{Dev}^{* 3} / \%$ \\
\hline 97.567 & 18.304 & 18.264 & 0.22 \\
51.818 & 13.026 & 12.999 & 0.21 \\
31.865 & 9.2701 & 9.2518 & 0.20 \\
21.085 & 6.5972 & 6.5878 & 0.14 \\
14.454 & 4.6950 & 4.6906 & 0.094 \\
10.083 & 3.3413 & 3.3390 & 0.069 \\
7.099 & 2.3778 & 2.3771 & 0.029 \\
5.020 & 1.6922 & 1.6918 & 0.024 \\
3.560 & 1.2043 & 1.2041 & 0.017 \\
2.528 & 0.85705 & 0.85691 & 0.016 \\
1.796 & 0.60993 & 0.60984 & 0.015 \\
1.277 & 0.43407 & 0.43386 & 0.048 \\
\hline
\end{tabular}

$*^{1}$ Experimental densities in the present work

$*^{2}$ Calculated densities from the EOS of Span et al. [18]

$*^{3} \operatorname{Dev}=100\left(\rho_{\text {exp }}-\rho_{\text {cal }}\right) / \rho_{\text {cal }}$

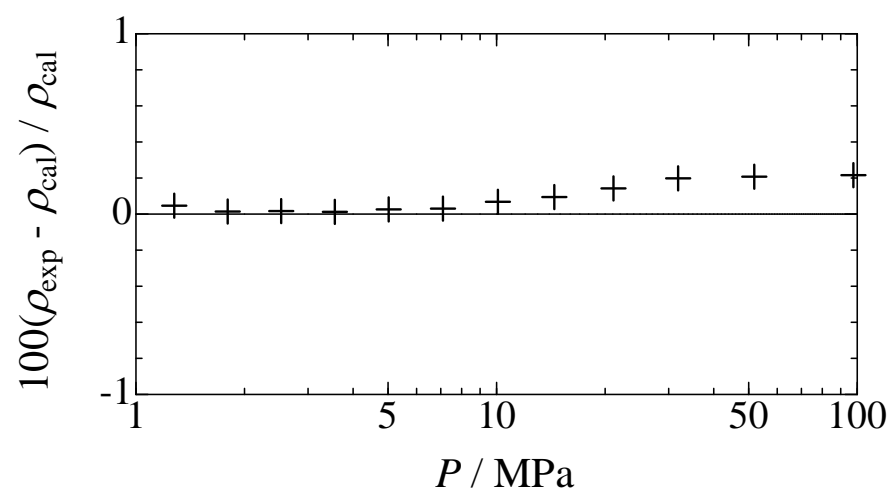

Fig. 9 Density deviations of nitrogen from the EOS of Span et al. [18]. ( +) The present work.

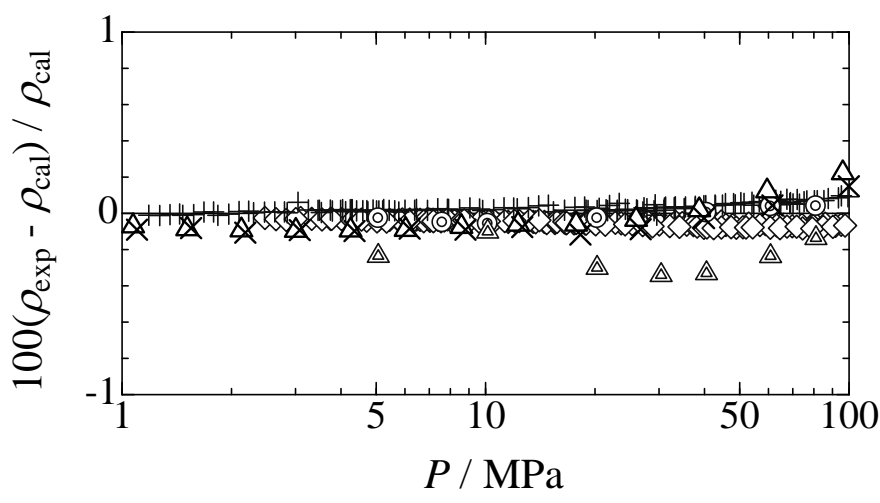

Fig. 10 Density deviations of hydrogen from the EOS of Leachman for normal hydrogen [19]. ( $\Delta$ ) Bartlett et al. [21], ( ○) Wibe and Gaddy [22], (十) Michels and Goudeket [23], $(\diamond)$ Michels et al. [20], ( $\Delta)$ The present work (Ser. 1), ( $\mathrm{X}$ ) The present work (Ser. 2).

\section{5 .結 論}

常温から $523 \mathrm{~K}, 100 \mathrm{MPa}$ までの温度 , 圧力領域で測定 可能なバーネット式 PVT 性質測定装置を開発した . 室素 の PVT 性質を温度 $353 \mathrm{~K}, 100 \mathrm{MPa}$ までの圧力範囲で測 定し, 既存の状態方程式と $0.22 \%$ 以内で一致する結果が 得られた . 同じ温度 , 圧力範囲で測定された水素の PVT 性質に関しては，同じく $0.22 \%$ 以内て既存の状態方程式 の値と一致した .これらの結果から，開発されたバーネ ット式 PVT 性質測定装置の信頼性および高圧高温への適 用性か確かめられた . 今後，さらに高温のデータを測定 し，信頼性の高い水素の PVT 性質を明らかにする .

\section{[謝辞]}

本研究は独立行政法人 新エネルギー・産業技術総合開 発機構(NEDO)による「水素先端科学基礎研究事業」の一 環として行われたものであり，ここに感謝の意を表する． また，本装置製作に際し，貴重なこ助言を頂いた，産業 技術厽合研究所 計測標準研究部門 物性統計科 流体標 準研究室 粥川洋平氏に感謝の意を表します．

\section{参考文献}

[1] R. D. Goodwin, D. E. Diller, H. M. Roder, L. A. Weber; J. Res. Natl. Bur. Stand., 67A (1963) 173-192.

[2] L. A. Weber; NASA-SP-3088 (1975).

[3] E. S. Burnett; J. Appl. Mech., 3 (1936) A136-140.

[4] B. Le Neindre, B. Vodar; Experimental Thermodynamics Volume II : Experimental Thermodynamics of Nonreacting Fluids, International Union of Pure and Applied Chemistry (IUPAC) (1975) 369-374, Butterworths, London.

[5] J. D. Cramer; Los Alamos, Lab. 3500 M S U C 34, Physics T I D 4500 (1965).

[6] F. B. Canfield, T. W. Leland, R. Kobayashi; J. Chem. Eng. Data, 10 (1965) 92-96.

[7] A. L. Blancett, K. R. Hall, F. B. Canfield; Physica, 47 (1970) 75-91.

[8] J. A. Provine, F. B. Canfield; Physica, 52 (1971) 79-91.

[9] K. R. Hall, F. B. Canfield; Physica, 47 (1970) 219-226.

[10] T. C. Briggs, D. J. Dalton, R. E. Barieau; Rep. Invest. US Bur. Min. No.7287 (1969).

[11] T. C. Briggs, A. R. Howard; PB Rep. US Nat. Tech. Inform. Serv. No.212481 (1972).

[12] J. Patek, J. Klomfar, J. Prazak, O. Sifner; J. Chem. Thermody., 30 (1998) 1159-1172.

[13] M. Waxman, J. R. Hastings; J. Res. Natl. Bur. Stand., 75c (1971) 165-176. 
[14] I. H. Silberberg, J. J. McKetta, K. A. Kobe; J. Chem. Eng. Data, 4 (1959) 323-329.

[15] S. P. Vohra, K.A. Kobe; J. Chem. Eng. Data, 4 (1959) 329-330.

[16] J. L. Belzile, S. Kaliaguine, R. S. Ramalho; Can. J. Chem. Eng., 54 (1976) 450-454.

[17] R. J. Witonsky, J. G. Miller; J. Am. Chem. Soc., 85 (1963) 282-286.

[18] R. Span, E. W. Lemmon, R. T Jacobsen, W. Wagner, A.Yokozeki; J. Phys. Chem. Ref. Data, 29 (2000) 1361-1433.

[19] J. W. Leachman; Fundamental Equations of State for Parahydrogen, Normal Hydrogen, and Orthohydrogen, Master's Thesis, University of Idaho (2007).

[20] A. Michels, W. de Graaff, T. Wassenaar, J. M. H. Levelt, P. Louwerse; Physica, 25 (1959) 25-42.

[21] E. P. Bartlett, H. L. Cupples, T. H. Tremearne; J. Am. Chem. Soc., 50 (1928) 1275-1288.

[22] R. Wiebe, V. L. Gaddy; J. Am. Chem. Soc., 60 (1938) 2300-2303.

[23] A. Michels, M. Goudeket; Physica, 8 (1941) 347-352.

[Received Nov. 9, 2009, Accepted Jan. 21, 2010] 